\title{
Complement Receptor Type 1
}

National Cancer Institute

\section{Source}

National Cancer Institute. Complement Receptor Type 1. NCI Thesaurus. Code C84439.

Complement receptor type 1 (2039 aa, $224 \mathrm{kDa}$ ) is encoded by the human CR1 gene.

This protein is involved in complement activation. 